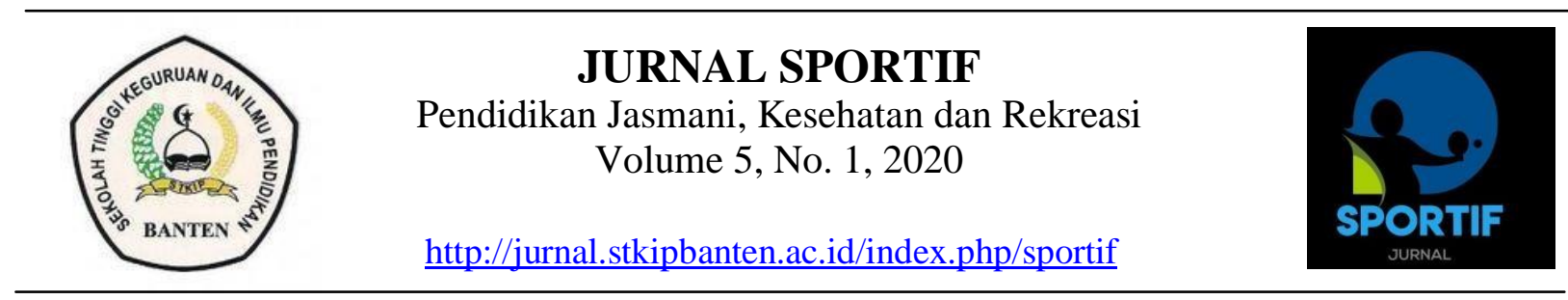

\title{
MINAT SISWA DALAM PERMAINAN BOLA VOLI MELALUI PENDEKATAN MODELLING PADA SISWA TUNAGRAHITA
}

\author{
Ahmad Yanuar Syauki ${ }^{1}$, Pardiman $^{2}$, Ade Saputra ${ }^{3}$ \\ ${ }^{1}$ Sekolah Tinggi Keguruan dan Ilmu Pendidikan Banten \\ ${ }^{2}$ Sekolah Tinggi Keguruan dan Ilmu Pendidikan Banten \\ ${ }^{3}$ Mahasiswa Pendidikan Jasmani kesehatan dan Rekreasi \\ 12aysyauki@yahoo.com, 2pardiman727@gmail.com,3ade7246@gmail.com
}

\begin{abstract}
ABSTRAK
Tujuan dari penelitian ini adalah untutk mengetahui minat siswa terhadap permainan bola voli melalui pendekatan modelling pada siswa tunagrahita. Motode yang digunakan dalam penelitian ini adalah metode literature yaitu merupakan cara pengumpulan data dengan cara data Primer dan Skunder. Instrumen yang digunakan dalam penelitian ini adalah data Primer yaitu data-data yang diambil dari buku-buku dan sedangkan data Skunder adalah data yang dapat menjelaskan tentang penelitian yaitu skripsi, jurnal dan dokumen hasil seminar. Simpulan dari penelitian menunjukkan, pembelajaran permianan bola voli melalui pendekatan modelling berpengaruh terhadap minat siswa tunagrahita. Maka dengan pendekatan modelling siswa dapat senang dan menirukan sehingga siswa dapat menyukai permainan bola voli pada anak tunagrahita.
\end{abstract}

Kata Kunci : Permianan Bola Voli, Pendektan Modelling, Tunagrahita 


\section{PENDAHULUAN}

Pendidikan jasmani di Indonesia memfokuskan untuk memperbaiki kualitas kesehatan dan kualitas kesegaraan jasmani melalui pemahaman, pengembangan sikap yang positif serta membiasakan hidup yang sehat. "bertujuan membantu siswa dalam meningkatkan dan memperbaiki derajat kesehatan dan kesegaran jasmani melalui pengertian pengembangan, sikap positif dan keterampilan gerak dasar serta berbagai aktivitas jasmani

Pendidikan jasmani adalah proses pendidikan yang memanfaatkan aktivitas jasmani yang direncanakan secara sistematik bertujuan untuk mengembangkan dan meningkatkan individu secara afektif, kognitif dan psikomotor dalam kerangka sistem pendidikan nasional. Pendidikan Jasmani pada dasarnya merupakan bagian integral dari sistem pendidikan secara keseluruhan, bertujuan untuk mengembangkan aspek kesehatan, kebugaran jasmani, keterampilan berfikir kritis, stabilitas emosional, keterampilan sosial, penalaran dan tindakan moral melalui aktivitas jasmani. Sebagai satuan proses pembinaan manusia yang berlangsung seumur hidup, peranan pendidikan jasmani sangatlah penting, karena memberikan kesempatan kepada siswa untuk terlibat langsung dalam semua pengalaman belajar melalui aktifitas jasmani, bermain dan olahraga yang dilakukan secara sistematis.

Pembekalan pengalaman belajar itu diarahkan untuk membina, sekaligus membentuk gaya hidup yang sehat dan aktif sepanjang hayat. Dalam penelitian ini, penulis memilih metode pendekatan modelling untuk menambah minat siswa tunagrahita dalam permaianan bola Voli

orang merai perhatian pada sesuatu, yang disertai dengan keinginan untuk mengetahui, memiliki, mempelajari, dan membuktikan. ${ }^{1}$ Minat terbentuk setelah di peroleh informasi tentang objek atau

\footnotetext{
${ }^{1}$ Pupu Saeful Rahmat, Psikologi Pendidikan . (Jakarta. Bumi Aksara. Th 2018)hlm.161
}

kemauan, disertai dengan keterlibatan perasaan, terarah pada objek atau kegiatan tertentu, dan terbentuk oleh lingkungan.

Tidak jauh berbeda dengan pendapat tersebut, Slameto menyatakan bahwa minat adalah suatu proses yang tetap untuk memperhatikan dan memfokuskan diri pada sesuatu yang diminati dengan perasaan senang dan rasa puas.

Minat merupakan suatu ketertarikan individu terhadap suatu objrk syang membuat individu merasa senang dengan objek tersebut. Pendapat lain yang dikemukakan oleh John Holland menyatakan bahwa minat adalah aktivitas atau tugas - tugas yang membangkitkan perasaan ingin tahu, perhatian, dan memberi kesenangan atau kenikmatan. ${ }^{2}$ Minat dapat menjadi indikator dari kekuatan seseorang di area tertentu tempat ia akan termotivasi untuk mempelajari dan menunjukkan kinerja yang tinggi.

Dalam hal ini, minat peserta didik dapat diartikan sebagai kecenderungan peserta didik terhadap objek atau suatu kegiatan, baik pelajaran maupun kegiatan lain di sekolah, yang digemari dan disertai dengan perasaan senang, adanya perhatian, serta keaktifan dalam melaksanakannya. Dalam hal ini, seorang peserta didik pasti memiliki kecenderungan untuk menyukai satu atau beberapa mata pelajaran dan kegiatan sekolah lain seperti ekstrakurikuler.

Minat juga memiliki jenis-jenis tertentu. Guilford menjabarkan jenis-jenis minat menjadi minat vokasional dan minat avokasional. Minat vokasional merujuk pada bidang pekerjaan tertentu. Minat vokasional terdiri dari (1) minat professional berupa minat keilmuan, seni, dan kesejahteraan sosial; (2) Minat komersial berupa minat pada dunia usaha, jual-beli, periklanan, akuntansi, dan kesekretariatan; serta (3) minat kegiatan fisik berupa kegiatan lun ar dan mekanik. Sementara itu, jenis minat kedua adalah minat avokasional yaitu minat yang merujuk pada minat untuk memperoleh kepuasan dan hobi. Minat avokasional ini

${ }^{2}$ Ibid 
dapat berupa petualangan, liburan, apresiasi. Dan ketelitian $^{3}$

\section{METODOLOGI PENELITIAN}

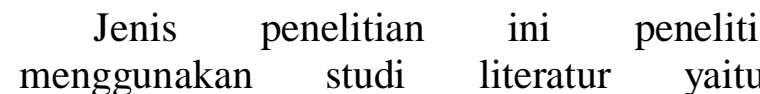
mengumpulkan data atau karya tulis ilmiah yang berkaitan dengan objek penelitian atau pengumpulan data yang bersifat kepustakaan, atau telaah yang dilaksanakan untuk memecahkan masalah yang pada dasarnya tertumpu pada penelaahan kritis dan mendalam terhadap bahan-bahan pustaka yang relevan.

Menurut Suarifqi Diantama studi literatur dilakukan dengan cara mempelajari dan mengkaji buku-buku atau sumber informasi tentang masalah yang diteliti, teknik ini selain digunakan untuk melengkapi serta memperkuat hasil penelitian yang dilakukan, teknik ini dilakukan dengan cara mengumpulkan berbagai macam sumber dan literatur bukubuku yang berkaitan dengan masalah yang sedang diteliti.

Menurut Amir Hamzah secara metodologis kepustakaan tergolong dalam jenis penelitian kualitatif, yaitu prosedur penelitian yang menghasilkan data berupa ucapan atau tulisan dan prilaku orang-orang yang diamati dalam suatu konteks tertentu dan holistik. Dalam konteks kepustakaan, maka data-data diambil dari eksplorasi bahan-bahan pustaka dikaji secara holistik, kemudian dianalisis berdasarkan kerangka berfikir atau teori tertentu/paradigma filosofis yang melandasinya, kemudian menggunakan pendekatan tertentu sesuai tujuan penelitian.

Menurut Mestika Zed riset pustaka tidak sekedar urusan membaca dan mencatat literatur atau buku-buku sebagaimana yang sering dipahami banyak

${ }^{3}$ Pupu Saeful Rahmat, Psikologi Pendidikan . (Jakarta. Bumi Aksara. Th 2018)hlm.162 orang selama ini, yang disebut riset kepustakaan atau sering juga disebut studi pustaka ialah serangkaian kegiatan yang berkenaan dengan metode pengumpulan data pustaka, membaca dan mencatat serta mengolah bahan penelitian.

Menurut Suarifqi Diantama studi literature dilakukan dengan cara mempelajari dan mengkaji buku-buku atau sumber informasi tentang masalah yang diteliti, teknik ini selain digunakan untuk melengkapi serta memperkuat hasil penelitian yang dilakukan, teknik ini dilakukan dengan cara mengumpulkan berbagai macam sumber dan literature bukubuku yang berkaitan dengan masalah yang sedang diteliti. ${ }^{4}$

\section{HASIL DAN PEMBAHASAN}

Pada bab ini akan dijelaskan mengenai deskripsi dari sumber yang digunakan mengenai. Mengenai sumbernya yang akan digunakan terdiri dari sumber primer dan skunder. Sumber primer adalah Data primer merupakan data yang diperoleh secara langsung pada objek penelitian yaitu proses - proses data yang menggunakan buku - buku. Sedangkan sumber sekunder adalah data yang diperoleh secara tidak langsung untuk mendukung penelitian seperti skripsi, artikel dan jurnal-jurnal lain yang mendukung.

Sebagai tahap awal, data dikelompokkan berdasarkan jenis sumbernya, yaitu data primer dan data sekunder.

1. Data Primer

Data primer merupakan data yang diperoleh secara langsung pada objek penelitian yaitu proses - proses data yang menggunakan buku - buku. Peneliti melakukan analisa terhadap buku - buku yang dikumplkan dan

\footnotetext{
${ }^{4}$ Suarifqi Dintam,M.Pd Metodo Penelitian Pendidikan ( Bandung Pustaka Rahmat, Tahun 2018) Hal. 34
} 
saling berhubungan dengan permainan kasti. Dari analisa dan pengamatan tersebut, peneliti mendapatkan data data yang dibutuhkan sebagai data primer. Data tersebut antara lain :

a. Muhajir. Jaja Mujahid, 2011.

Pendidikan Jasmani, Olahraga dan Kesehatan Untuk SMA dan MA Kelas $X$. Jakarta : Erlangga.

b. Jati Rinarki Atmaja,2018. Pendidikan dan Bimbingan Anak Berkebutuhan Khusus. Bandung : Remaja Rosdakarya

c. Pupu Saeful Rahmat, 2018. Psikologi Pendidikan. Jakarta : Bumi Aksara.

d. Rani Yulianty, 2011. Permainan yang meningkatkan Kecerdasan Anak. Jakarta : Niaga Swadaya.

e. Nani Triana, 2016. Pendidikan Anak Berkebutuhan Khusus Lamban Belajar Slow Lerner. Jakarta : Luxima Metro Media

\section{Data Sekunder}

Data sekunder adalah data yang diperoleh secara tidak langsung untuk mendukung penelitian. Data sekunder tersebut diperoleh dari hasil studi pustaka yang peneliti ambil dari berbagai jurnal, artikel dan media global internet. Data sekunder yang berhasil dikumpulkan untuk mendukung penelitian ini antara lain :

a. Qodli Zaka dengan Judul Penelitian "Minat Siswa Berkebutuhan Khusus Tunagrahita Dalam Mengikuti Pembelajaran Pendidikan Jasmani Di SLB C Yayasan Pendidikan Luar Biasa Demak Tahun 2016.

b. Akhmad Muhaimin dengan judul Penelitian 'Minat Siswa Dalam Mengikuti Ektrakurikuler Bola Voli Di Madrasah Aliya Sunan Pandanaran Tahun.

c. Galih Lian Prasetya dengan judul penelitian "Minat siswa kelas VIII SMP Negeri 4 Ngaglik terhadap pembelajaran Permainan bola voli tahun 2016. d. Sony Putra Dewantara dengan judul penelitian "Minat Anak Kebutuhan Khusu (ABK) Tunagrahita Ringan Terhadap Kegiatan Olahraga Kesehatan di SDLB Putra Malang".

e. Yoga Bagus Nugroho, dengan Judul penelitian "Survei Minat Siswa Tunarungu Pada Pendidikan Jasmani Adaptif di SDLB-B "Putera Asih" Kelurahan Balowerti Kota Kediri Tahun Ajaran 2016/2017”.

f. Duladi Lukman, dengan judul Penelitian "Survei Pelaksanaan Proses Pembelajaran Penjasorkes Pada Siswa di Sekolah Luar Biasa ( SLB )"

\section{SIMPULAN}

Simpulan dari Permainan Bola voli malalui pendekatan Modelling pada nk tunagrahita diantaranya:

1. Anak dapat mencontoh model yang diberikan oleh guru dan anak mudah memahaminya.

2. Membuat menarik anak tungrahita dalam melakukan permainan bola Voli.

3. Anak dapat belajar malalui pengalaman langsung maupun tidak langsung dengan mengamati tingkah laku orang lain berikut konsekuensinya

4. Siswa dapat Kecakapan sosial tertentu bisa diperoleh dengan mengamati dan mencontoh tingkah laku model.

5. Siswa dapat pengendalian diri yang dipelajari melalui pengamatan atas model

\section{DAFTAR PUSTAKA}

Alwisol. 2004. Psikologi Kepribadian. Malaang : UMM Press.

Atmaja. Jati, Rinarki. 2017. Pendidikan dan Bimbingan Anak Berkebutuhan Khsusu. Bandung :Rosdakarya.

Desiningrum. RD, (2016), Psikologi Anak Berkebutuhan Khusus, Psikosain, Bandung.

Duladi Lukman.2016. Survei Pelaksanaan Proses Pembelajaran Penjasorkes Pada 
Siswa di Sekolah Luar Biasa SLB http://journal.unnes.ac.id/sju/index.php /peshr

Geniofam. 2010. Mengasuh dan Mensukseskan Anak Berkebutuhan Khusus. Jogjakarta : Garai Ilmu.

Kemis.Ati Rosnawati. 2013. Pendidikan anak Berkebutuhan khusus Tunagrahita. Jakarta : LUXIMA.

Komalasari, Gantika. 2011. Teori dan Teknik Konseling. Jakarta : PT, Indeks.

Muhajir. Jaja Mujahid. 2011. .Pendidikan Jasmani, Olahraga dan Kesehatan Untuk SMA dan MA Kelas X. Jakarta.: Erlangga.

Mujib, Abdul dan Jusuf Mudzakir. 2001. Nuansa-nuansa Psikologi Islam. Jakarta Barat :PT.Raja Grafindo Persada.
Nugruho Yoga Bagus.2016. Survei Minat Siswa Tunarungu Pada Pendidikan Jasmani Adaptif di SDLB-B "Putera Asih" Kelurahan Balowerti Kota Kediri Tahun Ajaran 2016/2017”. http://simki.unpkediri.ac.id/mahasiswa/ file_artikel/2017/12.1.01.09.0166.pdf

Qodli Zaki. 2016. Skripsi Minat Siswa Berkebutuhan Khusus Tunagrahita Dalam Mengikuti Pembelajaran Pendidikan Jasmani di SLB-C Yayaysan Pendidikan Luar Biasa Demak. https://lib.unnes.ac.id/27239/.

Rahmat, Saeful Pupu. 2018. Psikologi Pendidikan . Jakarta : Bumi Aksara.

Salim, Nur, Muhammad. Strategi Konseling.2005. Surabaya : Unesa University Press. 